\title{
Gökkuşağı Alabalıklarında (Oncorhynchus mykiss) Görülen Lactococcus garvieae Enfeksiyonu ve Tedavisi ${ }^{[*]}$
}

\author{
Fikri BALTA ${ }^{1 *} \quad$ İsmail KARATAY ${ }^{2}$ \\ ${ }^{1}$ Recep Tayyip Erdoğan Üniversitesi, Su Ürünleri Fakültesi, Hastallklar Anabilim Dall, 53100, Rize, Türkiye \\ ${ }^{2}$ Recep Tayyip Erdoğan Üniversitesi Fen Bilimleri Enstitüsü, Su Ürünleri Anabilim Dall, 53100,Rize, Türkiye
}

Atıf yapmak için: Balta, F. \& Karatay, İ. (2021). Gökkuşağı Alabalıklarında (Oncorhynchus mykiss) Görülen Lactococcus garvieae Enfeksiyonu ve Tedavisi. Anadolu Çev. ve Hay. Dergisi, 6(4), 651-661.

How to cite: Balta, F. \& Karatay, İ. (2021). Lactococcus garvieae Infection and Treatment Observed in Rainbow Trout (Oncorhynchus mykiss). J. Anatolian Env. and Anim. Sciences, 6(4), 651-661.

iD: https://orcid.org/0000-0002-1823-5823 (iD): https://orcid.org/0000-0003-1205-0577

*Corresponding author:

Fikri BALTA

Recep Tayyip Erdoğan Üniversitesi, Su

Ürünleri Fakültesi, Hastalıklar Anabilim Dalı, Rize, Türkiye

凶: fikri.balta@erdogan.edu.tr
Öz: Bu çalışma, 2012 Ocak ve 2017 Eylül tarihleri arasında Doğu Karadeniz Bölgesi’ndeki 12 farklı Gökkuşağı alabalık çiftliklerinden balık örnekleri toplandı. Bu örneklerden toplam 100 adet bakteri izole edildi. Tüm izolatların tanımlanması geleneksel biyokimyasal testler, API 20 strep testi ve PZR testi kullanılarak yapıldı. Pozitif kontrol olarak ATCC 43921 referans izolat1 kullanıldı. API 20 strep test sonuçlarına göre izole edilen 100 bakteri izolatından 65 izolatın Lactococcus garvieae olduğu belirlendi. Bu izolatları moleküler olarak L. garvieae izolatına özel pLG-1 ve pLG-2 (16S rRNA) referans genleri kullanılarak PCR testi ile doğrulandi. Çalışmanın sonucunda, Gökkuşağı alabalıklarından izole edilen 100 izolattan 65'inin L. garvieae olduğu teyit edildi. Antibiyogram test sonuçlarına göre izolatların sulfamethoksazol, streptomisin ve sulfametoksazol+trimetoprim'e \%100, ampisiline \%94,2, oksitetrasiklin $\% 72,5$, eritromisine $\% 55,07$ ve oksolinik asit $\% 43,5$ oranında dirençli olduğu tespit edildi. Ek olarak enrofloksasin $\% 26,09$, doksisikline $\% 20,3$, amoksiklin ve florfenikole $\% 8,7$ oranında daha düşük seviyede direnç tespit edildi. Hastalığın tedavisinde, balık üreticisine antibiyogram test sonuçlarına göre en etkili olan florfenikol, amoksiklin ve doksisiklin antibiyotiklerden birinin kullanılması önerildi.

\section{Lactococcus garvieae Infection and Treatment Observed in Rainbow Trout (Oncorhynchus mykiss)}

*Sorumlu yazar:

Fikri BALTA

Recep Tayyip Erdogan University, Faculty of Fisheries, Department of Diseases, Rize, Turkey

$凶$ : fikri.balta@erdogan.edu.tr

\begin{abstract}
In this study, fish samples were collected from 12 different Rainbow trout farms in the Eastern Black Sea Region between January 2012 and September 2017. A total of 100 bacteria were isolated from these samples. Identification of all isolates were carried out by using conventional biochemical tests, API 20 strep tests and PCR tests. ATCC 43921 reference isolate was used as a positive control. According to API 20 strep test results, 65 isolates from 100 bacterial isolates were determined to be Lactococcus garvieae. These isolates were molecularly confirmed by PCR testing using the pLG- 1 and pLG-2 (16S rRNA) reference genes specific to $L$. garvieae isolate. It was confirmed by PCR testing using the reference genes pLG-1 and pLG-2 (16S rRNA) specific to the L. garvieae isolate. As a result of this study, 65 isolates out of 100 bacterial isolates isolated from diseased rainbow trout were confirmed to be $L$. garvieae. According to the antibiogram test results, the isolates were $100 \%$ resistant to sulfamethoxazole, streptomycin and sulfamethoxazole+trimethoprim, $94.2 \%$ to ampicillin, $72.5 \%$ to oxytetracycline, $55.07 \%$ to erythromycin and $43.5 \%$ to oxolinic acid. In addition, lower levels of resistance were detected with enrofloxacin $26.09 \%$, doxycycline $20.3 \%$, amoxicillin and florfenicol $8.7 \%$. In the treatment of the disease, the fish producer was advised to use one of the most effective antibiotics, florfenicol, amoxicillin and doxycycline, according to the antibiogram test results.
\end{abstract}

Keywords: Antimicrobial agents, API 20 strep, L. garvieae, PCR. 


\section{GİRIŞ}

Laktokokozis hastalığı ilk defa 1974 yılında Japonya'da kültürü yapılan sarıkuyruk (Seriola quinqueradiat) balıklarında görülen önemli bir bakteriyel hastalık etkeni olarak rapor edilmiştir (Kusuda vd., 1991; Çağırgan \& Tanrıkul, 1997; Kusuda \& Salati, 1999). Hastalık etkeni, Lactococcocus garvieae (Synonim=Enterecoccus seriolicida)'nın dünyanın farklı coğrafik bölgelerindeki tatlı ve tuzlu su balık türlerinde hastalık meydana getirdiği bildirilmiştir (Toranzo vd., 1994; Elder \& Ghittino, 1999; Muzquiz vd., 1999; Chen vd., 2001). L. garvieae enfeksiyonunun İspanya, İtalya, Portekiz, İngiltere, Fransa, Avustralya, Güney Afrika ve Asya ülkelerinde kültürü yapılan gökkuşağı alabalığı (O. mykiss) çiftliklerinde görüldüğü rapor edilmiştir (Çağırgan \& Tanrıkul, 1997; Elder \& Ghittino, 1999; Chang vd., 2002; Çağırgan, 2004; Türe vd., 2012, Balta \& Dengiz Balta, 2019). L. garvieae ile enfekte çiğ balık tüketilmesiyle insanlarda sporadik vakalar rapor edilmiștir (Wang vd., 2007). Dolaysıyla insanlardaki hastalık olgularından etkenin izole edilmisi etkenin zoonoz karakterini ortaya koymaktadır (Zlotkin vd., 1998; James vd., 2000; Mofredj vd., 2000; Vela vd., 2000; Yiu vd., 2007). Önceden Streptococcus garvieae olarak tanımlanan L. garvieae, ilk olarak İngiltere'deki mastitisli ineklerden izole edilmiștir (Collins vd., 1983). L. garvieae ile enfekte çiğ balık tüketilmesiyle insanlarda sporadik vakalar rapor edilmiştir (Wang vd., 2007). Ülkemizde ise 2001 yılında Ege Bölgesinde Gökkuşağı alabalığı işletmelerinde streptokokozis enfeksiyonun ortaya çıktığı ve yüksek mortaliteye neden olduğu bildirilmiştir (Çağırgan \& Tanrıkul, 1997; Diler vd., 2002; Altun vd., 2004). Ülkemizde Gökkuşağı alabalığı işletmelerinde son yıllarda ortaya çıkan L. garvieae enfeksiyonları hızlı bir yayılım göstermiş ve \%90'a varan ölümler yüzünden sürdürülebilir üretimi engelleyerek büyük ekonomik kayıplara neden olmuştur. Karadeniz bölgesinde, özellikle yaz aylarında dere ve baraj göllerinde kültürü yapılan her boy Gökkuşağı alabalıklarında yüksek su sıcaklığının yanı sıra yoğun stoklama, düşük su kalitesi ( $\mathrm{pH}$, amonyak, nitrit, vs) ve strese bağlı olarak ortaya çıkan hastalık vakalarında ölümlerin \%50-90’a ulaştığı ve büyük ekonomik kayıplara neden olduğu rapor edilmiştir (Türe vd., 2012; Balta \& Dengiz Balta, 2019).

Ülkemizde günümüze kadar; Kubilay vd. (2005), L. garvieae izolatlarında antimikrobiyal duyarlılıklarının belirlenmesi, Türe vd. (2012), Pulsed Field Gel Electrophoresis (PFGE) yöntemi kullanılarak $L$. garvieae'nın genetik varlığının ve yayılımının belirlenmesi, Öztürk vd. (2013), Orta Karadeniz Bölgesi’nde Gökkuşağı alabalıklarında antimikrobiyal hassasiyeti ve hastalık etkeninin tespit edilmesi, Türe vd. (2012), Doğu Karadeniz Bölgesi'ndeki Gökkuşağı alabalıklarında L. garvieae etkeni ve antimikrobiyal duyarlılığı ortaya konulması, Çağırgan (2004), Türkiye'den izole edilen L. garvieae izolatlarının biyotiplendirilmesi, Kav ve Erganiş, (2007) ise Konya Bölgesi'ndeki Gökkuşağı alabalığı (O. mykiss) çiftliklerinden toplanan hastalıklı balıkların iç organlarından L. garvieae'nın izolasyonu, identifikasyonu ve fenotipik özelliklerinin tespit edilmesi, Akşit ve Kum, (2008) gökkuşağı alabalıklarında oldukça sık rastlanılan patojen mikroorganizmaların varlığının belirlenmesi ve antimikrobiyallere karşı hassasiyet düzeylerinin tespit edilmesi gibi birçok çalışma yapılmıştır.

$\mathrm{Bu}$ çalışma ile Doğu Karadeniz Bölgesindeki Trabzon, Rize, Artvin, Gümüşhane, Ordu ve Erzurum il sınırları içerisinde yer alan ticari Gökkuşağı alabalığı işletmelerinde 6 yıl boyunca meydana gelen kok enfeksiyonlarının varlığının tespit edilmesi çalışılmıştır. $L$. garvieae ile kontamine işletmelerin belirlenmmesi ve hastalığın tedavisinde kullanılan antibiyotiklerin etkinliklerinin belirlenmesi amaçlanmıştır.

\section{MATERIAL AND METHOD}

Balık Örnekleri: Doğu Karadeniz Bölgesi'nde 2012-2017 y1llarının 12 farklı Gökkuşağı alabalığ1 çiftliğinden özellikle su sıcaklığının $18^{\circ} \mathrm{C}$ 'nin üzerine yükseldiği yaz mevsiminde hastalık semptomu gösteren ve ölmek üzere olan balıklardan her seferinde en az 10 balık laboratuvara laboratuvara getirildi. Örneklemede, rengi kararmış ve çift taraflı ekzoftalmus görülen balıkların seçilmesine özen gösterildi. $\mathrm{Bu}$ çalışma esnasında laboratuvara toplam 4320 adet (6 ay x 6 y1l x 10 balık x 12 çiftlik) gökkuşağı alabalığı analiz edildi. Laboratuvara getirilen balıklar öncelikle 2-phenoxy etanol ile derin anestezi altına alındı. Nekroskopide sonucunda bağırsakların boylu boyuna hemorajik olan, aynı zamanda hava kesesi üzerinde yaygın kanama alanların bulunan, karaciğerinde farklı derecede renk değişimleri görülen, karaciğer ve plorik sekanın üzerinde nokta şeklindeki kanamalar gözlenen balıklar kok enfeksiyonu yönünden şüpheli olarak ele alındı. Balıklarda görülen makroskopik bulgular, işletmelerde görülen mortalite oranları ve tedavi süresince uygulanan protokoller kayıt altına alınd.

Hastalı Etkenin izolasyonu: Balıkların ön böreğinden öze yardımı ile alınan örnekler lam üzerinde bir damla steril FTS $(\% 0,85 \mathrm{NaCl})$ ile karıştırılarak mikroskobun 40'l1k objektif altında incelendi. Hareketsiz ve kok olarak görülen bakteriler Gram boyama yöntemiyle boyand. Boyanan preparatlar 100'lük objektifte muayene edildi. Mikroskobik bakıda tek, ikili ve kısa zincirler (5-7 
kok) halinde mor renkte Gram pozitif olan bakterilerin $L$. garvieae olabileceği düşünüldü. Örnekleme yapılan Gökkuşağı alabalık işletmelerinin coğrafik yerleşimleri, örnekleme tarihi, izolasyonun yapıldığı organlar ve izolat numaralarına ait bilgiler Tablo 1'de verildi.

Mikroskobik kontrol sonrası balıkların özelikle böbrek, dalak, nadiren karaciğerlerinden ve eğer mevcutsa deri lezyonlarından Triptik Soy Agar (TSA) ve Broth (TSB), Brain Heart Infusion Agar (BHIA) ve Broth (BHIB)'a steril bir öze yardımı ile ekimler yapıldı. Ekzoftalmus semptomu gösteren ve bütünlüğünü koruyan (patlamamış) gözlerden steril öze ve swap yardımı ile göz içi sıvısından TSB'a ve TSA'ya aseptik olarak ekimler yapıldı. Bu besi yerleri $20 \pm 1^{\circ} \mathrm{C} 48$ saat inkübasyona bırakıldı. TSA'da 24 ve 48 saat sonunda üreyen küçük beyaz kolonilerin değerlendirilmeye alındı. Bu amaçla izole edilen bakterilere hareket muayenesi, Gram boyama, katalaz ve oksidaz testleri yapıldı ve hareketsiz, Gram pozitif, katalaz ve oksidaz testi negatif olan izolatlar seçildi. Çalışma esnasında izole edilen 100 bakteri izolatının TSA'da saf kültürleri üretildi. Bakterilere yapılan hareket muayenesinde hareketsiz, katalaz ve oksidaz testi negatif olan Gram boyamada mikroskobik sahada tek, ikili ve kısa zincir tarzında mor renkte olan toplam 65 adet izolat çalışmanın ilerleyen aşamalarında kullanılmak üzere seçildi. TSB'de üretilen bu izolatların taze kültürleri $\% 20$ gliserol içeren $1,5 \mathrm{ml}$ 'lik epondorf tüplerde $1 \mathrm{ml}$ hacimde homojenize edilip etiketlenerek $-80^{\circ} \mathrm{C}$ 'de derin dondurucuda çalışılmak üzere stoklandı.

Tablo 1. Gökkuşağı alabalıklarından izole edilen L. garvieae izolatlarına ait veriler.

Table 1. Data of $L$. garvieae isolates isolated from rainbow trout.

\begin{tabular}{|c|c|c|c|c|c|c|c|c|c|}
\hline No & $\overline{\mathbf{I} N}$ & Orijin & Yer & Tarih & No & $\dot{\mathbf{I} K}$ & Orijin & Yer & Tarih \\
\hline 1 & PY1 & Böbrek & Trabzon & 16.08 .17 & 34 & Y338 & Böbrek & Rize & 21.07 .13 \\
\hline 2 & FH20 & Böbrek & Rize & 14.09 .14 & 35 & Y449 & Böbrek & Trabzon & 04.08 .13 \\
\hline 3 & B116 & Böbrek & Trabzon & 13.08 .17 & 36 & B64 & Göz & Rize & 24.07.17 \\
\hline 4 & B157 & Böbrek & Trabzon & 23.08 .17 & 37 & B29 & Böbrek & Artvin & 01.07 .17 \\
\hline 5 & B173 & Göz & Sivas & 03.09 .17 & 38 & B67 & Dalak & Rize & 24.07 .17 \\
\hline 6 & B176 & Göz & Sivas & 03.09 .17 & 39 & B66 & Böbrek & Rize & 24.07 .17 \\
\hline 7 & B185 & Böbrek & Trabzon & 08.09 .17 & 40 & Y380 & Böbrek & Artvin & 18.07.13 \\
\hline 8 & B186 & Böbrek & Trabzon & 08.09 .17 & 41 & B36 & Böbrek & Rize & 02.07 .17 \\
\hline 9 & B187 & Böbrek & Trabzon & 08.09 .17 & 42 & B69 & Böbrek & Rize & 24.07 .17 \\
\hline 10 & B188 & Böbrek & Trabzon & 08.09 .17 & 43 & B70 & Dalak & Rize & 24.07.17 \\
\hline 11 & B193 & Böbrek & Rize & 09.09 .17 & 44 & B71 & Göz & Rize & 24.07.17 \\
\hline 12 & B197 & Böbrek & Rize & 09.09 .17 & 45 & B82 & Böbrek & Trabzon & 31.07 .17 \\
\hline 13 & B201 & Böbrek & Rize & 14.09 .17 & 46 & B84 & Böbrek & Trabzon & 31.07 .17 \\
\hline 14 & Y73 & Böbrek & Trabzon & 21.07 .14 & 47 & B85 & Böbrek & Trabzon & 31.07 .17 \\
\hline 15 & Y126 & Dalak & Trabzon & 28.08 .14 & 48 & B86 & Dalak & Trabzon & 31.07 .17 \\
\hline 17 & Y180 & Göz & Trabzon & 13.09 .14 & 50 & B88 & Böbrek & Trabzon & 31.07 .17 \\
\hline 18 & Y182 & Böbrek & Trabzon & 13.09 .14 & 51 & B89 & Göz & Trabzon & 31.07 .17 \\
\hline 19 & Y183 & Göz & Trabzon & 13.09 .14 & 52 & B90 & Göz & Trabzon & 31.07 .17 \\
\hline 20 & Y184 & Böbrek & Trabzon & 13.09 .14 & 53 & B114 & Göz & Trabzon & 13.08 .17 \\
\hline 21 & Y185 & Böbrek & Trabzon & 13.09 .14 & 54 & B115 & Göz & Trabzon & 31.07 .17 \\
\hline 22 & Y196 & Böbrek & Trabzon & 20.10 .14 & 55 & B116 & Göz & Erzurum & 13.08 .17 \\
\hline 23 & RT39 & Böbrek & Rize & 19.05.12 & 56 & B133 & Böbrek & Erzurum & 13.08 .17 \\
\hline 24 & $\mathrm{R} 83$ & Böbrek & Rize & 18.06.12 & 57 & B134 & Böbrek & Rize & 13.08 .17 \\
\hline 25 & R103 & Böbrek & Trabzon & 25.06 .12 & 58 & B135 & Böbrek & Rize & 13.08 .17 \\
\hline 26 & $\mathrm{R} 151$ & Böbrek & Trabzon & 06.07 .12 & 59 & B137 & Karaciğer & Rize & 13.08 .17 \\
\hline 27 & R164 & Böbrek & Rize & 21.07.12 & 60 & B149 & Böbrek & Trabzon & 23.08 .17 \\
\hline 28 & R165 & Böbrek & Rize & 21.07.12 & 61 & B 150 & Dalakk & Trabzon & 23.08 .17 \\
\hline 29 & R197 & Böbrek & Trabzon & 04.08 .12 & 62 & B 151 & Böbrek & Trabzon & 23.08 .17 \\
\hline 30 & R198 & Göz & Trabzon & 17.07.13 & 63 & B152 & Böbrek & Trabzon & 23.08 .17 \\
\hline 33 & B159 & Göz & Trabzon & 23.08 .17 & 66 & Ref. & Meme & ATCC & 1984-86 \\
\hline
\end{tabular}

İN: İzolat numarası. Ref.: L. garviae (ATCC 43921) referans suşu (Collins et.al 1984/Schleifer vd,. 1986).

IN: Isolate number. Ref.: L. garviae (ATCC 43921) reference strain (Collins et.al 1984/Schleifer vd., 1986).

Hastalık Etkenin Tantmlanmasl: L. garvieae izolatları $-80^{\circ} \mathrm{C}$ 'den çıkarılıp önce TSB'de üretildi. $\mathrm{Bu}$ izolatlar TSA'ya ekilerek saflık kontrolleri yapıldı. Kontamine olanlar izolatlar yeniden saflaştırıldı. Saflaştırılan izolatların tamamına hareket, gram boyama, katalaz ve oksidaz testleri yapıldı ve $\% 5$ koyun kanı ilave edilmiş kanlı agara ekildi. Kanlı agarda $25 \pm 1{ }^{\circ} \mathrm{C}$ 'de $24-48$ saat inkübasyona bırakıldı.

İzolatlarının kanlı agarda hemoliz oluşturup oluşturmadıkları kontrol edildi. Kanlı agarda üreyen izolatlar API 20 strep test kitine (bioMérieux, Fransa) talimatlarına uygun olarak inoküle edildi ve $25 \pm 1{ }^{\circ} \mathrm{C}$ 'de soğutmalı inkübatörde 24 ve 48 saat inkübasyona bırakıldı. 
API 20 strep test kitlerine 24 saat sonunda ayıraç dökülerek değerlendirme yapıldı. Şeker testleri için 48 saat sonunda son okuma yapılarak izolatlara ait biyokimyasal testlerin sonuçları değerlendirildi. API 20 strep kitlerine L. garvieae izolatlarının inokülasyon sonrası ilk görünümü Şekil 1'de verildi.

Bakteri Genomik DNA'ların Elde Edilmesi: L. garvieae izolatlarının genomik DNA's1 promega mini genomik DNA saflaştırma kiti kullanılarak üretici firma talimata uygun olarak gerçekleştirildi.

İolatlarının PZR'la Doğrulanması: L. garvieae izolatlarının tanımlanmasında $16 \mathrm{~S}$ rRNA geninden yararlanıldı. Moleküler identifikasyonda L. garvieae için spesifik olan oligonükleotid primerleri pLG-1 (5'CATAACAATGAGAATCGC-3') ve pLG-2 (5'GCACCCTCGCGGGTTG-3') kullanıldı (Zlotkin vd., 1998). API 20 strep test kitleri ile tanımlanan tüm izolatların L. garvieae olup olmadığının doğrulanması amacıyla bu primerler yardımıyla PZR testleri yapıldı ve test sonucunda 1100 bp büyüklüğünde PZR ürünün görülmesi pozitif sonuç olarak kabul edildi. Çalışmada L. garvieae ATCC 43921 referans suşupozitif ve Vibrio anguillarum genomik DNA'ları ise negatif kontrol olarak kullanıldı. PZR reaksiyonunda kullanılan kimyasallar ve konsantrasyonları ait bilgiler Tablo 2'de verildi. Bu çalışmada uygulanan PZR döngü koşullarına ait bilgiler Tablo 3'de verildi.

Tablo 2. PZR reaksiyonunda kullanılan kimyasallar ve konsantrasyonları.

Table 2. Chemicals used in the PCR reaction and their concentrations.

\begin{tabular}{lll}
\hline Kimyasallar & Konsantasyon & \\
\hline $5 \mathrm{X}$ Go Taq Buffer & & $5 \mu 1$ \\
$\mathrm{MgCl}_{2}$ & $25 \mathrm{mM}$ & $3 \mu 1$ \\
dNTP karışımı & $10 \mathrm{mM}$ & $4 \mu 1$ \\
Primer R & $10 \mathrm{pmol}$ & $0,5 \mu \mathrm{l}$ \\
Primer F & $10 \mathrm{pmol}$ & $0,5 \mu 1$ \\
Total DNA & $50(\mathrm{ng} / \mathrm{ml})$ & $2 \mu 1$ \\
Taq DNA Polimeraz & $5(\mathrm{U} / \mu \mathrm{l})$ & $0,25 \mu \mathrm{l}$ \\
$\mathrm{ddH}_{2} \mathrm{O}$ & & $9,75 \mu \mathrm{l}$ \\
Toplam & & $25 \mu 1$ \\
\hline
\end{tabular}

Tablo 3. Kullanılan primerler için PZR döngü şartları.

Table 3. PCR cycling conditions for the primers used.

\begin{tabular}{lccc}
\hline PZR Basamakları & Sıcaklık $\left({ }^{\circ} \mathbf{C}\right)$ & Zaman & Döngü Sayısı \\
\hline İlk Ayrılma & 94 & $3 \mathrm{dk}$ & 1 \\
Ayrılma & 94 & $1 \mathrm{dk}$ & 40 \\
Yapışma & 43 & $45 \mathrm{sn}$ & \\
Uzama & 72 & $1 \mathrm{dk}$ & 1 \\
Son Uzama & 72 & $10 \mathrm{dk}$ & \\
Bekleme & 4 & $\infty$ & \\
\hline
\end{tabular}

Disk Difüzyon Testi: İzolatların National Committee for Clinical Laboratory Standards (NCCLS, 1997) tarafından bildirilen standart disk difüzyon yöntemi ile antimikrobiyel duyarlılık testleri yapıldı ve değerlendirildi. Bu amaçla L. garvieae izolatlarının 18-24 saatlik taze kültürleri steril 1,5 ml'lik fizyolojik tuzlu su $(\% 0,9 \mathrm{NaCl})$ içeren tüplerde McFarland No: 0,5 bulanıklığına ayarlandı. .Her bir izolattan hazırlanmış olan süspansiyondan $0,1 \mathrm{ml}$ alınarak Müller Hilton Agar'a (MHA) yayma tarzında ekim yapıldı. Manual bir dispenser (Bioanalyse) yardımı ile antibiyotik diskleri MHA üzerine yerleştirildi. Çalışmada, ampisilin $(10 \mu \mathrm{g})$, oksitetrasiklin $(30 \mu \mathrm{g})$, gentamisin $(10 \mu \mathrm{g})$, sulfadiazin-trimetoprim (25 $\mu \mathrm{g})$, eritromisin $(15 \mu \mathrm{g})$, sulfametoksazol (25 $\mu \mathrm{g})$, enrofloksasin $(5 \mu \mathrm{g})$, florfenikol $(30 \mu \mathrm{g})$, oksolinik Asit (2 $\mu \mathrm{g})$, amoksiklin $(10 \mu \mathrm{g})$ ve streptomisin $(10 \mu \mathrm{g})$ antibiyotik diskleri (Bioanalyse, Türkiye) kullanıldı. Petri kutuları $25^{\circ} \mathrm{C}$ 'de 18 saat süresince inkübasyona birakıldı. Üreme sonrası antibiyotik disklerinin etrafında oluşan zon çapları dijital kumpas yardımı ile ölçüldü. Antibiyogram hassasiyetine ait test sonuçları Tablo 4'de verilen inhibisyon zon çapı standart aralıkları ile karşılaştırılarak değerlendirildi.

Tetrasiklin Direnç Genlerinin Tespiti: L. garvieae izolatların antibiyotik direnç genleri PZR testi kullanılarak tespit edildi. Spesifik primerler kullanılarak bakteri izolatların ilgili gen bölgeleri ayrı ayrı çoğaltılarak tetrasikline dirençli kılan hedef gen bölgeleri (tet $A$, tetB, tet $C$, tet $D$ ve tetE) varlığ belirlendi. Tetrasikline dirençli genlerinin tespiti için kullanılan primerlerin baz dizilimleri, gen bölgeleri, ürün boyları ve bağlanma sıcaklıkları Tablo 5 'de verildi.

Tablo 4. Antibiyotik disk konsantrasyonları ve standart inhibisyon zon çapları.

Table 4. Antibiotic disc concentrations and standard inhibition zone diameters.

\begin{tabular}{lrrrc}
\hline Antimikrobiyeller ve & \multicolumn{4}{c}{ Standart inhibisyon zon çapı (mm) } \\
\cline { 2 - 5 } Disk Konsantrasyonu & D & OH & H & Referanslar \\
\hline T-30 $\mu \mathrm{g}$ & $\leq 14$ & $15-18$ & $\geq 19$ & NCCLS (1997) \\
OA-2 $\mu \mathrm{g}$ & $\leq 10$ & $11-12$ & $\geq 13$ & NCCLS (1997) \\
SMZ 100 $\mu \mathrm{g}$ & $\leq 12$ & $13-16$ & $\geq 17$ & NCCLS (1997) \\
$\mathrm{AM}-10 \mu \mathrm{g}$ & $\leq 13$ & $14-16$ & $\geq 17$ & NCCLS (1997) \\
$\mathrm{AX}$ & $\leq 13$ & $14-17$ & $\geq 18$ & NCCLS (1997) \\
$\mathrm{FFC}-30 \mu \mathrm{g}$ & $\leq 14$ & $15-18$ & $\geq 19$ & NCCLS (1997) \\
S-10 $\mu \mathrm{g}$ & $\leq 11$ & $12-14$ & $\geq 15$ & NCCLS (1997) \\
ENR-5 $\mu \mathrm{g}$ & $\leq 16$ & $17-20$ & $\geq 21$ & NCCLS (1997) \\
E-15 $\mu \mathrm{g}$ & $\leq 13$ & $14-22$ & $\geq 23$ & NCCLS (1997) \\
SXT-25 $\mu \mathrm{g}$ & $\leq 10$ & $11-15$ & $\geq 16$ & NCCLS (1997) \\
\hline T: Oksitetrasiklin, OA: Oksolinik asit, SMZ: Sulfamethoksazol, AM: Ampisillin, FFC: Florfenikol, \\
S: Streptomisin, ENR: Enrofloksasin, E: Eritromisin, SXT: Trimethoprim+Sulfamethaksazol. D: \\
Dirençli, OH: Orta hassas, H: Hassas.
\end{tabular}

Tablo 5. Tetrasiklin'e dirençli gen primerleri ve PZR döngü şartları.

Table 5. Tetracycline resistant gene primers and PCR cycling conditions.

\begin{tabular}{|c|c|c|c|c|c|}
\hline Primer & Hedef gen & Sekans (5' - 3') & Gen büyüklüğü (bp) & Bağ. sıcaklığı $\left({ }^{\circ} \mathbf{C}\right)$ & Literatürler \\
\hline $\begin{array}{l}\text { tetA-F } \\
\text { tetA-R }\end{array}$ & Tet A & $\begin{array}{l}\text { GCT ACA TCC TGC TTG CCT TC } \\
\text { CAT AGA TCG CCG TGA AGA GG }\end{array}$ & $210 \mathrm{bp}$ & 56 & Ng vd., 2004. \\
\hline $\begin{array}{l}\text { tetB-F } \\
\text { tetB-R }\end{array}$ & Tet $B$ & $\begin{array}{l}\text { TTG GTT AGG GGC AAG TTT TG } \\
\text { GTA ATG GGC CAA TAA CAC CG }\end{array}$ & 659 bp & 54 & Ng vd., 2004. \\
\hline $\begin{array}{l}\text { tetC-F } \\
\text { tetC } R\end{array}$ & Tet $C$ & $\begin{array}{l}\text { CTT GAG AGC CTT CAA CCC AG } \\
\text { ATG GTC GTC ATC TAC CTG CC }\end{array}$ & $418 \mathrm{bp}$ & 56 & Ng vd., 2004. \\
\hline $\begin{array}{l}\text { tetD-F } \\
\text { tetD R }\end{array}$ & Tet $D$ & $\begin{array}{l}\text { AAA CCA TTA CGG CAT TCT GC } \\
\text { GAC CGG ATA CAC CAT CCA TC }\end{array}$ & $787 \mathrm{bp}$ & 55 & Ng vd., 2004. \\
\hline
\end{tabular}




\begin{tabular}{|c|c|c|c|c|c|}
\hline $\begin{array}{l}\text { tetE-F } \\
\text { tetE R }\end{array}$ & Tet $E$ & $\begin{array}{l}\text { CGG CGT GGG CTA CCT GAA CG } \\
\text { GCC GAT CGC GTG AAG TTC CG }\end{array}$ & $1180 \mathrm{bp}$ & 56 & Guardabassi vd., 2000. \\
\hline
\end{tabular}

\section{BULGULAR}

Doğu Karadeniz Bölgesindeki Trabzon, Rize, Artvin, Gümüşhane, Ordu, Sivas ve Erzurum illerindeki 12 farklı Gökkuşağı alabalığı çiftliğinden (karasal havuzlardan ve baraj göllerinde bulunan yüzer ağ kafesler) yaz aylarında yapılan örneklemeler sonucu toplam 100 bakteri izolatı elde edildi. $\mathrm{Bu}$ izolatların tamamına geleneksel biyokimyasal testler (Gram pozitif, katalaz ve oksidaz testi negatif) yapıldı ve testlerin sonuçlarına göre L. garvieae olabileceği düşünülen 65 izolata API 20 strep testi yapıld1. L. garvieae ATCC 43921 referans suşuna da API 20 strep testi yapıldı ve pozitif kontrol olarak kullanıldı. Standart suşun test sonuçları ile klinik izolatların test sonuçları karşılaştırılarak izolatların $L$. garvieae olabileceğine karar verildi. APİ 20 strep kitlerine L. garvieae izolatlarının inokülasyon sonrası ilk görünümü Şekil 2'de verildi.

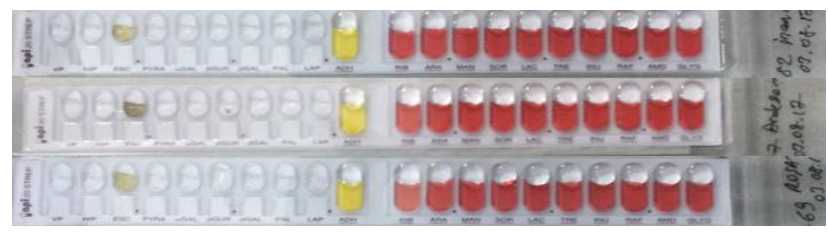

Şekil 1. API 20 strep kitlerine L. garvieae izolatlarının inokülasyon sonrası ilk görünümü.

Figure 1. First appearance of $L$. garvieae isolates after inoculation in the API 20 strep kits.

Klinik semptomlar ve nekropsi bulgulart: $\mathrm{Bu}$ çalışmada, alabalık çiftliklerindeki havuzlardan örnekleme yapılırken özellikle kok hastalığı için tipik makroskobik bulgu olarak renkte kararma ve gözlerde çift taraflı ekzoftalmus gösteren hasta balıklar örneklendi. Hasta balıkların su yüzeyinde halsiz bir şekilde yüzdüğü gözlemlendi. Bazı balıkların havuz çıkış suyuna toplandığı, bazı balıkların ise stresli olduğu, hızlı bir şekilde hareket ettiği ve havuz dibine kaçtığı görüldü. Hastalığın ileri vakalarında özellikle her iki gözünde ekzoftalmusun ve beraberinde gözün etrafinda beyaz bir halka teşkil ettiği görüldü. Hastalığın kronik safhasında balıkların gözlerinin tek veya çift taraflı matlaşarak kör olduğu tespit edildi. Balıkların bazılarında ise gözün yerinden çıkmış olduğu ve göz çukurunun boş olduğu görüldü. Ayrıca balıklarda anüs etrafinda hafif bir kızarıklığın olduğu tespit edildi.

Hastalıklı semptomu gösteren Gökkuşağı balıklarının nekropsisinde karaciğerin solgun olduğu ve bazen üzerinde nadiren peteşial kanamaların varlığı tespit edildi. Benzer şekilde pilorik sekalar üzerinde peteşial kanamalar tespit edildi. Bağırsakların şişkin, hemorajik ve beyaz bir içerikle dolu olduğu belirlendi. Hava kesesi üzerinde yaygın kanamaların varlığı dikkat çekici bir bulgu olarak rastlanıldı. L. garvieae'nın gökkuşağı alabalıklarında oluşturduğu hastalığın semptomları Şekil 2'de verildi.

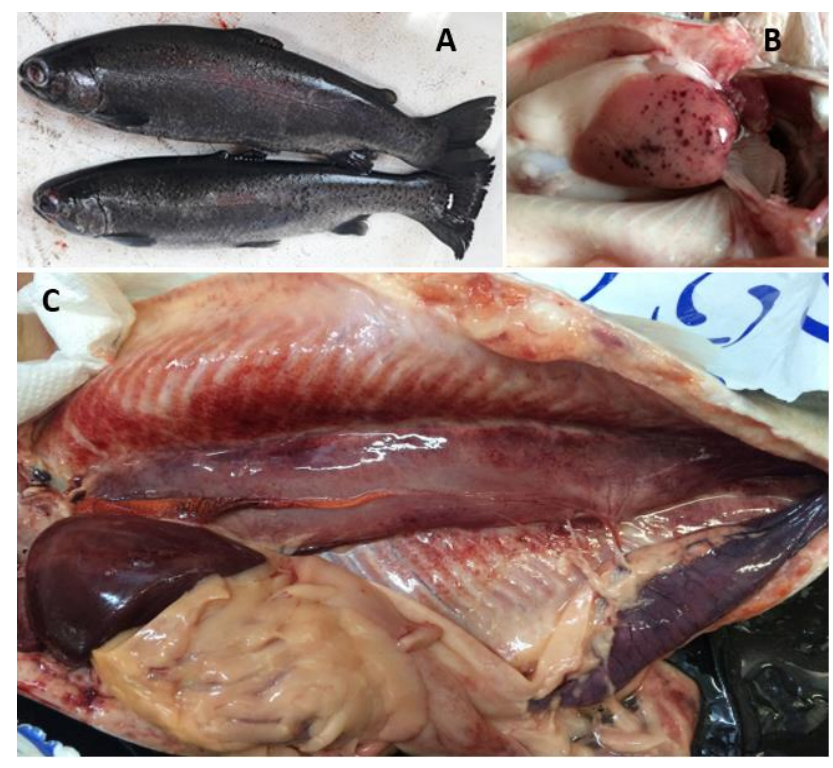

Şekil 2. Lactococcozis' in semptomları A) Renkte kararma, B) Karaciğerde solgun görünüm ve nokta şeklinde kanamalar, C) Hava kesesi üzerinde noktasal kanama ve bağırsakta yaygın kanama.

Figure 2. Symptoms of Lactococcosis A) Darkening in color, B) Pale and petechial hemorrhaging on the liver, C) The congestion in the gut and petechial hemorrhaging on the air bladder.

Fiziksel ve Biyokimyasal Test Sonuçlart: Gökkuşağı alabalıklarındaki ortaya çıkan kok enfeksiyonlarından elde edilen izolatlara yapılan testlerde etkenin hareketsiz olduğu, mikroskobik bakıda bakterilerin Gram pozitif, yuvarlak (kok), ikili oval veya 6-7 koktan oluşan kısa zincirler tarzında görüldüğü belirlendi. $\mathrm{Bu}$ çalışmasında elde edilen izolatlara ait fiziksel ve biyokimyasal test sonuçları Tablo 6'de verilmiştir. $L$. garvieae'nın gökkuşağı alabalıklarında oluşturduğu hastalığın septomları Şekil 3'de verildi.

API 20 strep test sonuçları: L. garvieae referans suşu (ATCC 43921) ile yapılan APİ 20 strep test sonuçlarına ait verilerin görünümü Şekil 4‘de verilmiştir. Hastalıklı gökkuşağı alabalıklardan izole edilen $L$. garvieae izolatlarının APİ 20 strep test kitlerine inoküle edildikten 24 saat sonra ayıraç dökülmeden önceki görünüm Şekil 5'de, ayıraçlar döküldükten sonraki görünümü ise Şekil 6'de verildi. APİ 20 strep test kitine ait biyokimyasal verileri L. garvieae referans suşuna ait API 20 strep test kitinin biyokimyasal test sonuçları ile 
karşılaştırılarak değerlendirildi. L. garvieae referans suşunun API 20 strep test kitinde; Voges Proskuer (VP), Hippurat hidroliz (HP), Eskulin hidroliz (ESC), Pirrolidonil arilamidaz (PYRA), lösin arilamidaz (LAP) ve Arjinin dihidrolaz (ADH) pozitif iken $\alpha$ Galaktosidaz ( $\alpha$ GAL), $\beta$ Glukuronidaz ( $\beta$ GUR) $\beta$ Galaktosidaz ( $\beta$ GAL) Alkalin fosfataz (PAL) negatif reaksiyon verdiği belirlendi. Ayrıca aynı kitteki karbonhidrat testlerinden asit üretiminde; Riboz (RIBB), Mannitol (MAN), Trehaloz (TRE) ve Amigdalin (AMD) pozitif reaksiyon iken, Arabinoz (ARA), Sorbitol (SOR), Laktoz (LAC), İnulin (INU), Rafinoz (RAF) ve Glikojen (GLYG) negatif reaksiyonlar verdiği tespit edildi. APİ 20 sterp testi sonuçlarına göre çoğunun 7143115 profili gösterdiği espit edildi. İzolatlara yapılan APİ 20 strep test kitleri ile yapılan testlerin sonuçları Tablo 7'de verilmiştir.

Tablo 6. $L$. garvieae izolatlarına ait geleneksel ve API 20 strep test sonuçları.

Table 6. Conventional and API 20 strep test results of $L$. garvieae isolates.

\begin{tabular}{|c|c|c|c|}
\hline \multirow{2}{*}{$\begin{array}{l}\text { Fenotipik test sonuçları } \\
\text { Şekil (kok=K) }\end{array}$} & \multicolumn{2}{|c|}{ Api 20 strep testi } & \multirow[b]{2}{*}{$+(66 / 66)$} \\
\hline & K (66/66) & VP & \\
\hline Hareket & $-(66 / 66)$ & HIP & $+(66 / 66)$ \\
\hline Gram & $+(66 / 66)$ & ESC & $+(66 / 66)$ \\
\hline Katalaz & $-(66 / 66)$ & PYRA & $+(66 / 66)$ \\
\hline Oksidaz & $-(66 / 66)$ & $\alpha \mathrm{GAL}$ & $-(66 / 66)$ \\
\hline $\mathrm{OF}$ & $\mathrm{F}(66 / 66)$ & $\beta$ GUR & $-(66 / 66)$ \\
\hline $\mathrm{H}_{2} \mathrm{~S}$ & $-(66 / 66)$ & $\beta \mathrm{GAL}$ & $+(66 / 66)$ \\
\hline İndol & $-(66 / 66)$ & PAL & $-(64 / 66)$ \\
\hline Lysin & $-(66 / 66)$ & LAP & $-(66 / 66)$ \\
\hline Ornitin & $-(66 / 66)$ & ADH & $+(66 / 66)$ \\
\hline Arjinin & $+(66 / 66)$ & RIB & $+(66 / 66)$ \\
\hline Nitrat & $-(66 / 66)$ & ARA & $-(66 / 66)$ \\
\hline MR testi & $+(66 / 66)$ & MAN & $+(66 / 66)$ \\
\hline VP testi & $-(66 / 66)$ & SOR & $-(66 / 66)$ \\
\hline SS testi & $-(66 / 66)$ & LAC & $+(40 / 66)$ \\
\hline Eskulin & $+(66 / 66)$ & TRE & $+(66 / 66)$ \\
\hline$\% 0 \mathrm{NaCl}$ & $+(66 / 66)$ & INU & $-(66 / 66)$ \\
\hline$\% 6,5 \mathrm{NaCl}$ & $+(66 / 66)$ & RAF & - $(39 / 66)$ \\
\hline$+10^{\circ} \mathrm{C}$ & $+(66 / 66)$ & AMD & $+(66 / 66)$ \\
\hline$+20^{\circ} \mathrm{C}$ & $+(66 / 66)$ & GLYG & $-(66 / 66)$ \\
\hline$+45^{\circ} \mathrm{C}$ & $+(66 / 66)$ & *Hemoliz & $\alpha(66 / 66)$ \\
\hline
\end{tabular}
Hippurat hidroliz, ESC: Eskulin hidroliz, PYRA: Pirrolidonil arilamidaz, $\alpha \mathrm{GAL}: \alpha$ Galaktosidaz, $\beta$ GUR: $\beta$ Glukuronidaz, $\beta$ GAL: $\beta$ Galaktosidaz, PAL: Alkalin fosfataz, LAP: Lösin arilamidaz, ADH: Arjinin dihidrolaz, RIB: Riboz, ARA Arabinoz, MAN: Mannitol, SOR: Sorbitol, LAC: Laktoz, TRE: Trehaloz, INU: İnulin, RAF: Rafinoz, AMD: Amigdalin ve GLYG: Glikojen. *Hemoliz: \%5 koyun kanı ila edilmiş standart agarda yapıldı.

K: Coc, F: Fermentative, MR: Methyl Red, VP: Voges-Proskauer, SS: SimonCitrate, HP: Hippurate hydrolysis, ESC: Esculin hydrolysis, PYRA: Pyrrolidonyl arylamidase, $\alpha \mathrm{GAL}: \alpha$ Galactosidase, $\beta \mathrm{GUR}$ : $\beta$, Glucuronidase, $\beta \mathrm{GAL}: \beta$ Galactosidase, PAL: Alkaline phosphatase, LAP: Leucine arylamidase, ADH: Arginine dihydrolase, RIB: Ribose, ARA: Arabinose, MAN: Mannitol, SOR Sorbitol, LAC: Lactose, TRE: Trehalose, INU: Inulin, RAF: Raffinose, AMD Amygdalin and GLYG: Glycogen. *Hemolysis: It was done on standard agar supplemented with 5\% sheep blood.

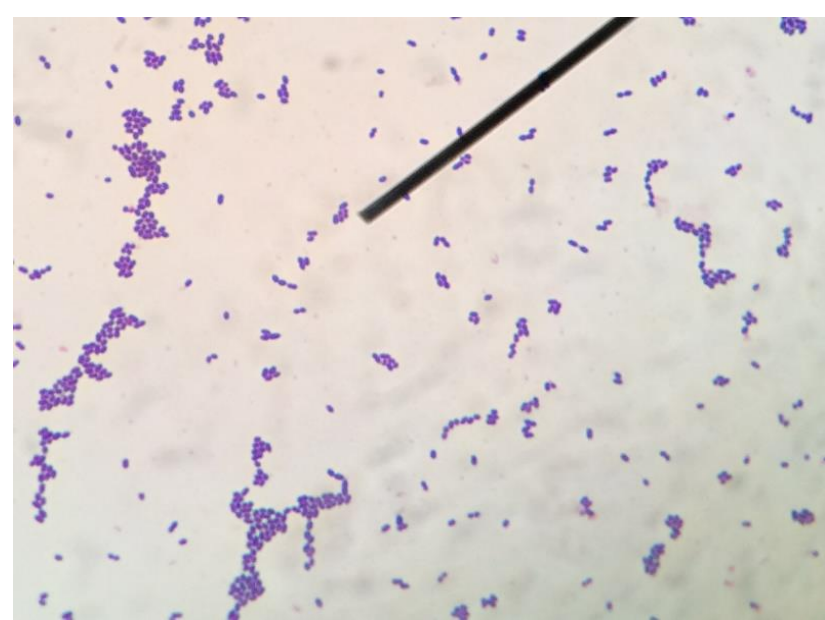

Şekil 3. Gram boyanmış $L$. garvieae izolatının mikroskobik görünümü. Figure 3. Microscopic appearance of Gram-stained L. garvieae isolate.

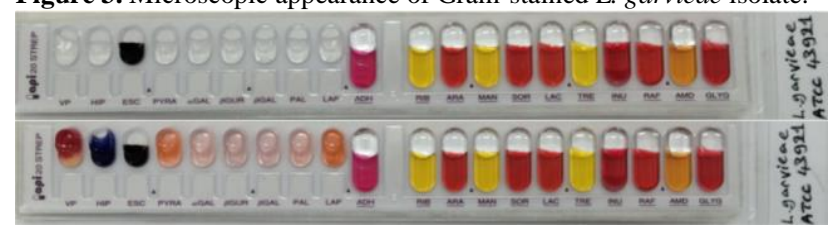

Şekil 4. API 20 strep test kitindeki L. garvieae referans izolatının (ATCC43921) ayıraçlar dökülmeden önceki ve döküldükten sonraki biyokimyasal testlerin sonuçları.

Figure 4. Results of biochemical tests of the reference isolate (ATCC43921) of L. garvieae in the API 20 strep test kit before and after pouring the reagents.

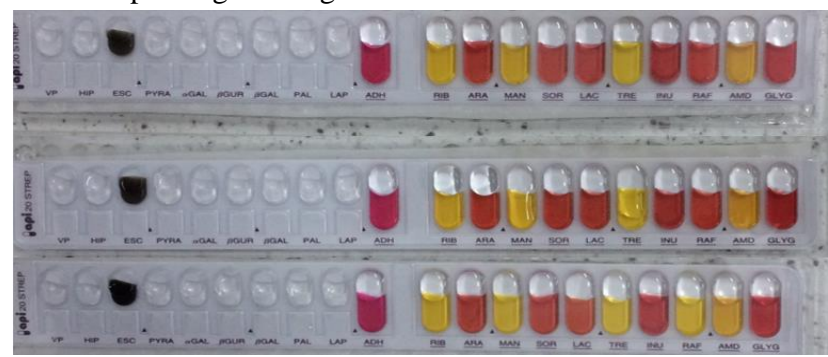

Şekil 5. L. garvieae izolatları için API 20 strep testinde biyokimyasal test sonuçlarının ilk görünümü.

Figure 5. First view of biochemical test results in the API 20 strep test for L. garvieae isolates.

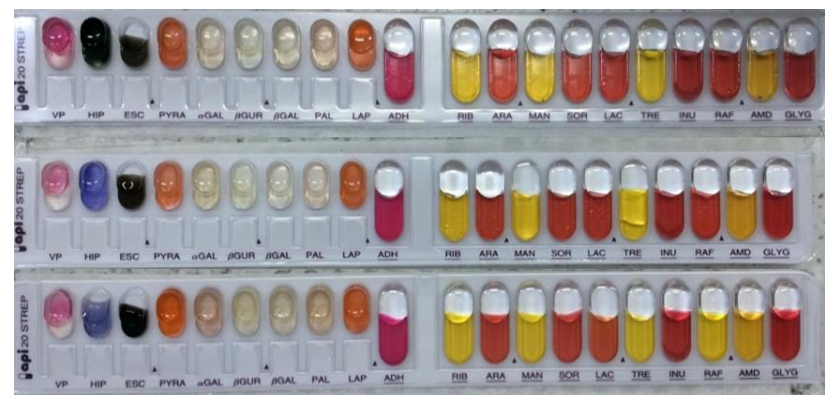

Şekil 6. L. garvieae izolatları için API 20 strep testinde ayıraçlar döküldükten 10 dakika sonra biyokimyasal test sonuçlarının görünümü.

Figure 6. Appearance of biochemical test results 10 minutes after pouring reagents in API 20 strep test for L. garvieae isolates. VP: Voges Proskuer, HP: Hippurat hidroliz, ESC: Eskulin hidroliz, PYRA: Pirrolidonil arilamidaz, $\alpha \mathrm{GAL}: \alpha$ Galaktosidaz, $\beta$ GUR: $\beta$ Glukuronidaz, $\beta \mathrm{GAL}: \beta$ Galaktosidaz, PAL: Alkalin fosfataz, LAP: Lösin arilamidaz, ADH: Arjinin dihidrolaz, RIB: Riboz, ARA: Arabinoz, MAN: Mannitol, SOR: Sorbitol, LAC: Laktoz, TRE: Trehaloz, INU: İnulin, RAF: Rafinoz, AMD: Amigdalin ve GLYG: Glikojen. 
PCR test Sonuçları: Klasik yöntemle identifiye edilen 100 izolattan 65 izolatın L. garvieae olduğu düşünülerek bu izolatlara API 20 strep testi yapıldı. Test sonuçları API web sisteminde L. garvieae olmadığı ve farklı Lactococcus spp., türlerine değişik oranda benzerlik göstermesinden dolayı izolatların tanımlanması fenotipik olarak doğru bir şekilde yapılamadığı tespit edildi. $\mathrm{Bu}$ yüzden izole edilen bakterilerden elde edilen genomik DNA'lar1 pLG-1 ve pLG-2 primerleri kullanılarak 16S rRNA gen bölgesi PZR ile çoğaltıldı. Pozitif kontrol olarak referans suşu (ATCC 43921) kullanıldı. L. garvieae referans suşunun (ATCC 43921) 1100 bp büyüklüğünde PZR ürünü verdiği görüldü. Negatif kontrol olarak $V$. anguillarum kullaıldı. Bu çalışmada sonuçta toplam 65 adet izolatın genetik olarak $L$. garvieae olduğu teyit edildi. L. garvieae izolatlarına ait PZR görüntüleri Şekil 7'de gösterildi.

\section{$M 123455678$ V $91011 \quad 1213 \quad 14 \quad 15 \quad 16 \quad 17 \quad 18$

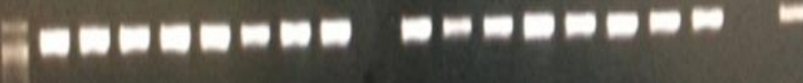

Şekil 7. L. garvieae izolatlarına ait PZR ürünlerin agaroz jel görünümü.

Figure 7. Agarose gel appearance of PCR products of L. garvieae isolates.

M; Markır (100-1500 bp), 1: L. garvieae (ATCC 43921); V: V. anguillarum, 17 Negatif kontrol (saf su), 2-8, 9-16, 18, L. garvieae saha izolatları

Antbiyogram test sonuçları: Çalışmada kullanılan izolatlara yapılan antibiyogram testinde tespit edilen sonuçlarına göre izolatların sulfamethoksazol, streptomisin ve sulfametoksazol+trimetoprime $\% 100$, ampisiline \%94,2, oksitetrasiklin \%72,5 oranlarında yüksek düzeyde dirençli olduğu, diğer antibiyotiklere karşı sirasiyla; eritromisine \%55,07, oksolinik asit \%43,5, enrofloksasin \%26,09, doksisikline \%20,3, amoksiklin ve florfenikol \%8,7 düzeyinde direnç gösterdiği tespit edildi. L. garvieae izolatlarına karşı amoksisilin ve florfenikolün \%91,3, doksikline \%79,7 oranında etkili olduğu belirlendi. Antibiyotiklere karşı L. garvieae izolatlarının belirlenen hassasiyet ve direnç yüzdelik profilleri Şekil 8'de verildi.

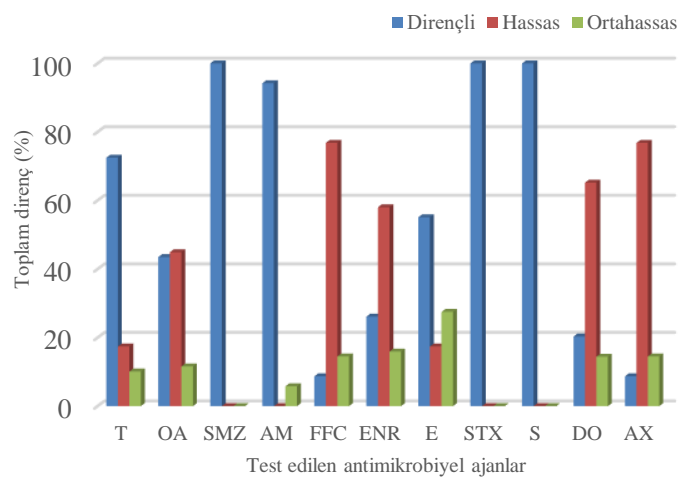

Şekil 8. $L$. garvieae izolatlarının farklı antibiyotiklere gösterdiğ direnç profilleri.

Figure 8. Resistance profiles of $L$. garvieae isolates to different antibiotics.

Tetrasiklin Direnç Genlerinin Tespiti: Çalışmada tetrasiklin direnç genleri taramasında moleküler düzeyde 65 adet $L$. garvieae izolatından 13 izolatta tet $A, 8$ izolatta $t e t B, 11$ izolatta tet $C, 15$ izolatta $t e t D$ ve 25 izolatın tet $E$ direnç genine rastlanıldı̆̆ 1 tespit edildi. Antibiyogram test sonuçlarına göre tetrasiklinlere $\% 72,5$ direnç tespit edilen izolatlardan 16,22 ve 23 sira nolu izolatlarda tetA, tetB, tet $C$, tetD ve tetE moleküler düzeyde direnç genlerinde hiçbirine rastlanılmadığı belirlendi.

\section{SONUÇ VE TARTIŞMA}

$\mathrm{Bu}$ çalışmanın sonuçlarına göre hastalıklı gökkuşağı alabalıklardan izole edilen 65 izolatların ve 1 adet referans suşun (ATCC 43921) biyokimyasal olarak yapılan APİ 20 strep testi sonuçlarına göre çoğu 7143115 profili göstermiştir. Aynı izolatların L. garvieae ait 1100 bp büyüklüğünde olan pLG-1 ve pLG-2 oligonukleotid primerleri ile genetik olarak yapılan PZR test sonuçlarına göre L. garvieae olduğu doğrulanmıştır. $\mathrm{Bu}$ izolatların antimikrobiyel ajanlara duyarlığını belirlemek için agar disk difüzyon yöntemi ile yapılan antibiyogram test sonuçlarına göre 3 farklı antimikrobiyel ajana \%100 dirençli olduğu belirlenmiştir. Antibiyograma duyarlıklı test sonuçlarına göre izolatların $\% 72,5$ oranında oksitetrasiklin ve $\% 20,3$ doksisikline dirençli olması nedeni ile yapılan moleküler düzeyde tetrasiklinlere dirençli genlerin varlığı tespit edilmeye çalışılmıştır. $\mathrm{Bu}$ çalışmada moleküler düzeyde 65 izolattan 13 izolatın tetA, 8 izolatın tet $B, 11$ izolatın tet $C, 15$ izolatın tet $D$ ve 25 izolatın tet $E$ direnç genine rastlanıldığı tespit edilmiştir. Antibiyogram testinde tetrasiklinlere \% 72,5 direnç tespit edilen izolatlardan 16,22 ve 23 sira nolu izolatlarda tet $A$, tet $B$, tet $C$, tet $D$ ve tet $E$ direnç genlerinde hiçbirine rastlanılmadığı belirlenmiştir. Ayrıca, tetG, tetM, tetO, tet $Q$ ve tet $W$ gibi pirimerler kullanılarak tetrasikline direnç genlerin varlığının da genetik olarak çalışılması gerektiği düşünülmüştür. 
Tetrasiklin direnci, sucul ortamda antibiyotik direnç genlerinin tespitine yönelik çalışmalarda sıklıkla belirleyici olduğu bildirilmiştir. Doğu Karadeniz Bölgesi'ndeki mevcut nehirlerden izole edilen Enterobacteriacea familyasına ait bakterileri izolatlarının tetrasiklin direnç genlerinin (tetA, tetB, tetC, tetD ve tetE) varlı̆̆ını tespit ettikleri bir araştırmada 52 tetrasiklin dirençli bakteri izolatından 8'inde tetA, 10'unda tetB ve 1 'inde ise her iki direnç genine rastlanılmasına karşın tetC, tetD ve tetE direnç genlerine ise hiç rastlanılmadığ bildirilmiştir (Sandallı vd., 2010). Doğu Karadeniz Bölgesi'ndeki gökkuşağı alabalık çiftliklerindeki hastalıklı balıklardan izole edilen oksitetrasikline dirençli Yersinia ruckeri izolatlarında 16 izolatın tetA, 2 izolatın tet $B, 3$ izolatın ise hem tet $A$ hem de tet $B$ direnç genin varlığınına sahip olduğu ve nehir sularının insan sağlığını risk altında tutan antibiyotik direnç genleri için bir rezervuar olabileceğini bildirmiştir (Balta vd., 2010). Ülkemizde 29 adet $L$. garvieae izolatına ait genomik DNA'sında moleküler düzeyde 12 farklı primer kullanılarak yapılan bir çalışmada; tetrasikline (tetB, tetS), eritromisine (ereA, ereB), sulfonamide (sull, sulII), $\beta$-laktam (ampC, blaTEM, blaPSE), trimetophrim ( $d h f r 1)$, aminoglikoside (aadA), ve florfenikol $(f l o R)$ en yüksek düzeyde 19 izolatın $e r e B, 20$ izolatın tetB ve 2 izolatın tet $S$, 3 izolatın sull ve 13 izolatın sull1, 12 izolatın blaTEM ve 14 izolatın floR moleküler düzeyde direnç genlerinin varlı̆̆ rapor edilmiştir (Türe ve Boran, 2015). Başka bir çalışmada ise 25 adet $L$. garvieae'nın saha izolatları arasında moleküler düzeyde bir izolatın sulI direnç genine, altı izolatın (\%24) sulII direnç genine ve bir izolatın tetD direnç genine sahip olduğu bildirilmiştir. Fakat aynı çalışmada izolatların hiç birinde moleküler düzeyde; $\mathrm{ermB}, \mathrm{erm} F$, floR, tetA, tetB, tetC, tetE tet $G$ ve $d h f r l$ direnç genlerinin varlığına rastlanılmadığı bildirilmiştir (Hancı \& Onuk, 2018).

L. garvieae su sicaklığının $18^{\circ} \mathrm{C}$ 'nin üzerine çıktığı yaz mevsiminde gerek tatlı su gerek deniz balıklarında septisemiye neden olduğu, gökkuşağ 1 alabalıklarında $\% 50$ 'den daha fazla ölüm meydana getirdiği ve önemli ekonomik kayıplara neden olan önemli bir bakteriyel hastalık olduğu rapor edilmiştir (Austin \& Austin, 2012). Etkilenen balıklarda gözlenen dış bulgular arasında tek ya da çift taraflı ekzoftalmi, gözde periorbital ve intraoküler bölgede, yüzgeçlerin tabanda, perianal bölgede hemorajiler, abdominal kısımda şişkinlik ve anal prolapsusun varlığı bildirilmiştir (Altun vd., 2004; Kav ve Erganiş, 2007; Durmaz \& Kılıçoğlu, 2015; Balta \& Dengiz Balta, 2019). Nekropside peritoneal asidik sıvı birikimi, karaciğer, dalak ve böbrek dahil iç organlarda hemoraji, dalak ve karaciğerde fokal nekroz ile barsakta kanlı sivı birikimi gözlenir (Altun vd., 2004; Kav \& Erganiş, 2007; Durmaz \& Kilıçoğlu, 2015; Balta \& Dengiz Balta, 2019). L. garvieae'nın Doğu Karadeniz Bölgesindeki farklı gökkuşağı alabalığı işletmelerinde gözlenen hastalık çıkışlarından sorumlu olup olmadıklarının araştırıldığı bu çalışmada su sıcaklığını $18^{\circ} \mathrm{C}$ olduğu Haziran-Temmuz aylarında başlayıp su sıcaklı̆̆ının $15^{\circ} \mathrm{C}$ 'nin altına düştüğü Ekim ayında enfeksiyonun hızla bir şekilde azaldığı tespit edilmiştir. Farklı işletmelerden yapılan örnekleme çalışmalarında hastalıktan etkilenen balıklarda genel olarak iştahsızlık, durgunluk, renkte kararma, gözlerde bilateral ekzoftalmusi, hemoraji ve opaklaşma, vücutta abdominal şişkinlik ve anal bölgede prolapsus ile solungaçların ise solgun olduğu tespit edilmiştir. Nekropside, vücut kası ile hava kesesinde yaygın hemorajiler, dalağın renginde koyulaşma, splenomegaly, barsağın boylu boyunca kızarık olduğu ve sarımsı renkli kanlı bir sıvı birikimi gözlenmiştir. Hasta balıklarda gözlenen bu bulgular, diğer araştırmacılar (Altun vd., 2004; Kav \& Erganiş, 2007; Durmaz \& Kılıçoğlu, 2015) tarafindan L. garvieae ile enfekte gökkuşağ alabalıklarından bildirilen bulgulara benzerlik gösterdiği tespit edilmiştir.

L. garvieae fakültatif anaerobik, hareketsiz, spor oluşturmayan, Gram-pozitif kok şeklindeki bir bakteridir. Mikroskopik görünümde hücreler, çiftler ve kısa zincirler şeklinde bulunmaktadır. L. garvieae kanlı agarda $\alpha$ hemoliz oluştururken, sitokrom oksidaz ve katalaz negatiftir (Kav \& Erganiş, 2007; Austin \& Austin, 2012). Altun vd. (2004) gökkuşağı alabalıklarından izole edilen sekiz $L$. garvieae izolatının sitokrom oksidaz ve katalaz negatif, VP pozitif olduğunu, $4^{\circ} \mathrm{C}$ ile $45^{\circ} \mathrm{C}$ de gelişme gösterdiklerini, glikoz, fruktoz, galaktoz, mannitol ve sakkarozu fermente ettiklerini bildirmiştir. izolatlar $\alpha$ hemolitik olup MacConkey agarda koloni oluşturmuştur. Söz konusu izolatlar nişasta ve jelatini hidrolize edemezken, \%6.5 NaCl'de gelişme göstermiştir. Kav ve Erganiş (2007) çalışmalarında 30 adet L. garvieae izolatının glikoz, galaktoz, mannitol, sakkaroz, fruktoz ve arabinoz'dan asit üretimlerinin pozitif olduğunu ancak sorbitol ile ksilozdan asit üretimlerinin ise negatif olduğunu bildirmiştir. Bu çalışmada L. garvieae izolatının Gram-pozitif, fermentatif, sitokrom oksidaz ve katalaz negatif, VP testin pozitif olduğu tespit edilmiştir. Çalışmada kullanılan izolatların hemoliz testi, $45^{\circ} \mathrm{C}$ ve $\%$ $6,5 \mathrm{NaCl}$ de üreme testi, glikoz, galaktoz, mannitol ve sakkaroz fermentasyon testlerinin pozitif olması diğer çalışmalarının sonuçları ile benzerlik göstermiştir (Anshary vd., 2014, Altun vd., 2004; Kav \& Erganiş, 2007). Bu çalışmada izolatların sorbitol ve ksilozdan asit üretimlerinin pozitif olup Kav ve Erganiş (2007) ise çalıştıkları $L$. garvieae izolatlarının sorbitol ve ksilozdan asit üretimlerinin negatif olduğunu bildirmiştir.

İzolatların API 20 strep test sonuçları API web sisteminde L. garvieae'nın özelliklerine ait bir veri bulunmadığından için sisteme girilen izolatların 7143115 
kod profili L. lactis subsp. lactis \% 57,9, Enterococcus faecalis \%24,1, E. durans \%14,5 ve E. faecium \%3,3 türlerinin biyokimyasal testlerinin benzerliğinden dolayı bu etkenleri birbirinden kesin olarak ayırt edilemediği ve yanlış identifikasyona neden olunabildiği belirlenmiştir. $\mathrm{Bu}$ neden yanlış identifikasyonu önlemek için $L$. garvieae'nın referans suşun (ATCC 43921) ile hem API 20 strep testi yapılarak test sonuçları değerlendirildiği gibi moleküler çalışmada aynı referans suşun genomik DNA'sı çıkartılarak PZR'da pozitif kontrol olarak kullanılmıştır. Kav ve Erganiş (2007), 30 L. garvieae izolatının API 20 strep testinin 24 saatlik test sonuçlarına göre $\% 90$ oranında L. lactis subsp. lactis ve \%6.6 oranında da E. faecalis'e benzerlik gösterdiğini bildirilmiştir. Bu çalışmamızda 65 izolatın API 20 strep test sonuçlarının, Kav ve Erganiş (2007) tarafından elde edilen sonuçlara benzerlik gösterdiği belirlenmiştir. Biyokimyasal özelliklerdeki farklar, bir organizmanın fizyolojik profili üzerine önemli bir bilgi vermesine karşın, fenotipik özellikler ile tek başına tür seviyesinde yeterli tanımlama yapılamamaktadır.

Moleküler teknikler ile patojenik türleri tanımlama ve tür ile izolatlar arasındaki farkı ayırt edebilmek mümkün olduğu rapor edilmiştir (Vale vd., 2000). L. garvieae izolatları arasındaki genetik çeşitliliği belirlemek için RAPD (Rastgele amplifiye edilmiş polimorfik DNA) tekniğini kullanılarak yapılan bir çalışmada, izolatların 1100 bp'lik spesifik amplifikasyon ürününü verdiği bildirilmiştir (Ravelo vd., 2003). Bu çalışmadaki 68 L. garvieae izolatının identifikasyonu için uygulanan PZR tekniği sonuçlarına göre izolatların 1100 bp'lik amplikasyon ürününü verdiği belirlenmiştir. Elde edilen sonuçların Ravelo vd. (2003) ve Zlotkin vd. (1998) tarafindan bildirilen sonuçlar ile uyumlu olduğu tespit edilmiştir. Aynı bölgedeki gökkuşağı alabalık çiftliklerinden ekzofthalmus semptomu gösteren balıkların gözlerinden yapilan ekim sonucunda izole edilen $L$. garvieae izolatlarının antibiyogram test sonuçları ile birebir örtüştüğü tespit edilmiştir (Balta \& Dengiz Balta, 2019). Kav ve Erganiş (2007) çalışmalarında L. garvieae izolatlarının ampisilin, oksitetrasiklin ve eritromisine hassas olduklarını, Durmaz ve Kılıçoğlu (2015), ise izole ettikleri L. garvieae izolatlarının ampisilin, eritromisine hassas, trimetoprim'e ise dirençli olduklarını bildirmiştir. Türe ve Boran (2015), ampisilinin L. garvieae izolatlarına karşı en etkili ajanlardan birisi olduğunu bildirmiştir. $\mathrm{Bu}$ çalışmada ise izolatların eritromisine $\% 45$ oranında duyarlı olması ile Kav ve Erganiş (2007), Durmaz ve Kılıçoğlu (2015) ve Türe ve Boran (2015)'ın sonuçlarına benzerlik göstermesine karşın, bu araştırmacılardan farklı olarak izolatların oksitetrasikline \%72,5 oranında dirençli olması ve ampisiline karşı ise izolatların \%100 dirençli olduğu belirlenmiştir.
Sonuç olarak bu çalışmanın bulgularına göre, hastalıklı gökkuşağı alabalıklarından izole edilen bakteriyel etkenlerin gerek fenotipik tanı test sonuçlarına ve gerekse moleküler PZR teknikleri kullanılarak yapılan çalışmanın sonuçlarına göre L. garvieae olarak izole ve identifiye edilmiştir. Gökkuşağı alabalık işletmelerindeki suyun sıcaklığg $18^{\circ} \mathrm{C}$ 'nin üzerine ulaştığı yaz mevsiminde örnekleme çalışması yapılan bölgede görülen hastalık vakalarından sorumlu başlıca etken L. garvieae'nın olduğu tespit edilmiştir. Bu çalışma sonuçlarına göre izolatların en az üç antimikrobiyal ajana \%100 dirençli olduğu belirlemiştir. $\mathrm{Bu}$ durum, işletme şartlarında yanlış doz ve sürede kullanılan antimikrobiyal ajanlara karşı bakterilerde artan direnç ile açıklanması mümkündür. Farklı çalışmalarda bakterideki direnç gelişimi artmakla olduğu ve bu direnç gelişiminin ortamda bulunan diğer bakteri türlerine de değişik yollarla aktarılabileceğini düşündürmektedir. Antibiyogram duyarlılık testi sonuçları hastalığa karşı mevcut aşıların kullanılması ve yeni aşı çalışmalarının geliştirmesi gerektiğini düşünülmektedir.

Gökkuşağı alabalık çiftliklerinde yaz aylarında ortaya çıkan kok enfeksiyonlarında kitleler halinde ölümlere neden olmaktadır. Gökkuşağı alabalık çiftliklerinde gerçekleşen toplu ölümler nedeni ile ortaya çıkan büyük ekonomik kayıpların varlığı akuakültürdeki sürdürülebilir üretimi kisıtlamaktadır. $\mathrm{Bu}$ bağlamda hastalığın erken teşhis ve tedaviye erken başlanması sürdürülebilir bir üretim için şarttır. Bunun için yaz aylarında üretici ve/veya su ürünleri mühendisleri su sıcaklığının yanı sıra çevresel şartlardaki değişimleri ve suyun $\mathrm{pH}$ değerlerini mutlaka takip etmelidir. Balıklarda görülen sporadik ölümler dikkate alınmalı ve en yakın balık hastalıkları laboratuvarına gönderilip muayenesi yapıldıktan sonra ekimler yapılarak hastalığın etkeni tespit edilmelidir. Balıklardaki az miktarda görülen ölümler dikkate alınmayıp geç kalındığı vakalarda su sıcaklığının yüksek olması ve sudaki oksijen bağlama kapasitesinin düşük olması balıklarda oluşan iştah kaybına bağlı olarak ölüm oranları şiddetli bir şekilde artırmaktadır. Hastalık etkeninin 24 saat içinde TSA ve BHIA gibi besi yerlerinde uygun sicaklıkta üremesi ve antibiyogram testlerinin yapılarak uygun kemoterapotik maddelerin zamanında ve uygun dozda verilmesi tedavi başarısını artırmaktadır. $\mathrm{Bu}$ amaçla bölgemizdeki alabalık çiftliklerinde yapılan arazi çalışmaları ile bütün çiftliklerin kontamine olduğu tespit edilmiştir. Yapılan antibiyogram hassasiyet test sonuçlarına göre amoksiklin, florfenikol ve doksiklin gibi antibiyotiklerden birinin uygun doz ve sürede kullanılması başarılı sonuçların alındığı gözlenmiştir. Ayrıca antibiyotiklerle birlikte polivitaminler veya su sıcaklığına bağlı stresi azaltmak için özellikle vitamin C kullanımının faydalı olduğu düşünülmektedir. 


\section{TEŞEKKÜR}

Hazırlanan bu Yüksek Lisans Tezi; Recep Tayip Erdoğan Üniversitesi, Bilimsel Araştırma Projeleri tarafindan desteklen 2014.103.02.3 nolu projeden üretilmiştir.

\section{KAYNAKLAR}

Akşit, D. \& Kum, C., 2008. Gökkuşağı alabalıkları (Oncorhynchus mykiss, Walbaum 1792)'nda s1k görülen patojen mikroorganizmaların tespiti ve antibiyotik duyarlılık düzeylerinin belirlenmesi. YYÜ Vet Fak Derg., 19(1), 1-7.

Altun, S., Diler, O. \& Adiloğlu, A.K. (2004). Genotyping of Lactococcus garvieae strains from rainbow trout (Oncorhynchus mykiss) by 16S rDNA sequencing. Bull. Eur. Ass. Fish Pathol., 24, 119125.

Anshary, H., Kurniawan, R.A., Sriwulan, S., Ramli, R. \& Baxa, D.V. (2014). Isolation and molecular identification of the etiological agents of streptococcosis in Nile tilapia (Oreochromis niloticus) cultured in net cages in Lake Sentani, Papua, Indonesia. SpringerPlus, 3:627, 1-11. DOI: $10.1186 / 2193-1801-3-627$

Austin, B. \& Austin, D.A. (2012). Bacterial Fish Pathogens. Diseases of Farmed and Wild Fish. 5th ed., 17-118, Springer Science, Dordrech.

Balta, F. \& Dengiz Balta, Z. (2019). The isolation of Lactococcus garvieae from eyes of diseased rainbow trout (Oncorhynchus mykiss) with exopthalmia. Anatolian Env. and Anim. Sciences, 4(1), 27-33. DOI: 10.35229/jaes.527258

Balta, F., Sandalli, C., Kayis, S. \& Ozgumus, O.B., 2010. Molecular analysis of antimicrobial resistance in Yersinia ruckeri strains isolated from rainbow trout (Oncorhynchus mykiss) grown in commercial fish farms in Turkey. Bull. Eur. Ass. Fish Pathol., 30(6), 211-219.

Chang, P.H., Lin, C.W. \& Lee, C. (2002). Lactococcus garvieae infection of cultured rainbow trout, $O$. mykiss in Taiwan and associated biophysical characteristics and histopathology. Bulletin of the European Association of Fish Pathologists, 25(5), 319-327.

Chen, S.C., Lin, Y.D., Liaw, L.L. \& Wang, P.C. (2001). Lactococcus garvieae infection in the giant freshwater prawn Macrobrachium rosenbergii confirmed by polymerase cahin reaction and 16SrDNA sequencing. Dis. Aquat. Org., 45, 4552. DOI: $10.3354 /$ dao045045

Collins, M.D., Farrow, J.A., Phillips, B.A. \& Kandler, O. (1983). Streptococcus garvieae sp. nov. and Streptococcus plantarum sp. nov. J Gen Microbiol, 129, 3427-3431. DOI: $10.1099 / 00221287-129-11-3427$
Çağırgan, H. \& Tanrıkul, T.T. (1997). A Lactococcus in a trout farm. Mediterranean Fisheries Congress, 9-11 April, Izmir, Turkey, 40p.

Çağırgan, H. (2004). Biotyping of Lactococcus garvieae isolated from Turkey. E.U. Journal of Fisheries \& Aquatic Sciences, 21(3-4), 267-269.

Diler, Ö., Altun, S., Adiloğlu, A.K., Kubilay, A. \& Işılklı, B.I. (2002). First occurence of streptococcosis affecting farmed rainbow trout (Oncorhynchus mykiss) in Turkey. Bulletin of the European Association of Fish Pathologists, 22, 21-26.

Durmaz, Y. \& Kılıçoğlu, Y. (2015). Bir alabalık çiftliğinde doğal enfekte gökkuşağ 1 alabalıklarından (Oncorhynchus mykiss, Walbaum, 1792) Lactococcus garvieae'nin kültür ve PCR ile saptanması ve etkenin antibiyotik duyarlılık profillerinin belirlenmesi. Atatürk Üniversitesi Vet. Bil. Derg., 10(2), 109-115. DOI: 10.17094/avbd.58682

Eldar, A. \& Ghittino, C. (1999). Lactococcus garvieae and Streptococcus iniae infections in rainbow trout (Onchorhynchus mykiss): Similar, but different diseases. Diseases of Aquatic Organisms, 36, 227-231. DOI: $10.3354 /$ dao036227

Hancı, I. \& Onuk E.E. (2018). Lactococcus garvieae izolatlarının antimikrobiyal direnç profillerinin fenotipik ve genotipik olarak belirlenmesi. Etlik Vet Mikrobiyol Derg, 29(2), 94-103.

James, P.R., Hardman, S.M.C. \& Patterson, D.L.H. (2000). Osteomyelitis and possible endocarditis secondary to Lactococcus garvieae: A first case report. Postgrad Med. J., 76, 301-303. DOI: 10.1136/pmj.76.895.301

Kav, K. \& Erganiş, O. (2007). Konya bölgesinde bulunan gökkuşa alaballgı (Onchyrnus mykiss) çiftliklerinden Lactococcus garvieae izolasyonu, identifikasyonu ve fenotipik özelliklerinin belirlenmesi. Vet. Bil. Derg., 23(1), 7-17.

Kubilay, A., Altun, S., Uluköy, G. \& Diler, Ö. (2005). The determination of antimicrobial susceptibilities of Lactococcus garvieae strains. Eğirdir Su Ürünleri Fakültesi Dergisi, 1, 39-48.

Kusuda, K., Kawai, K., Salati, F., Banner, C.R. \& Fryer, J.L. (1991). Enterococcus seriolicida sp. nov., a fish pathogen. International Journal of Systematic and Evolutionary Microbiology, 41(3), 406-409. DOI: 10.1099/00207713-41-3406

Kusuda, R. \& Salati, F. (1999). Enterococcus seriolicida and Streptococcus iniae. In (eds. Woo PTK, Bruno, D.W.) Fish Diseases and Disorders, Vol: 3, Viral, Bacterial and Fungal Infections. CABI Publishing, 303-317pp.

Mofredj, A., Baraka, D., Kloeti, G. \& Dumont, J.L. (2000). Lactococcus garvieae septicemia with liver abscess in an immuno-suppressed patient. Am. J. Med., 109(6), 513-514. DOI: 10.1016/S0002-9343(00)00534-9

Muzquiz, J.L., Royo, F.M., Otega, C., Blas, I., Ruiz, I. \& Allonso, J.L. (1999). Pathogenicity of 
Streptococcosis in rainbow trout (Oncorhynchus mykiss) dependence on age of diseased fish.

Bulletin of the European Association of Fish Pathologists, 19(3), 114-119.

Öztürk, T., Didinen, B.I., Doğan, G., Özer, A. \& Bircan, R. (2013). Lactococcosis in rainbow trout (Oncorhynchus mykiss, Walbaum, 1792) in the middle Black Sea Region in Turkey and antimicrobial susceptibility of the aetiological agent, Lactococcus garvieae. Etlik Vet. Mikrobiyol Derg., 24, 7-12.

Ravelo, C., Magariños, B., López-Romalde, S. \& Toranzo, A.E. (2003). Molecular fingerprinting of fish-pathogenic Lactococcus garvieae strains by random amplified polymorphic DNA analysis. J. Clin. Microbiol., 41, 751-756. DOI: 10.1128/JCM.41.2.751-756.2003

Sandallı, C., Özgümüş, O.B. \& Sevim, A., 2010. Characterization of tetracycline resistance genes in tetracycline-resistant Enterobacteriaceae obtained from a coliform collection. World Journal of Microbiology and Biotechnology, 26(11), 2099-2103.

Toranzo, A.E., Devesa, S., Heinen, P., Riaza, A., Nunez, S. \& Barja, J.L. (1994). Streptococcosis in cultured turbot caused by an Enterococcus-like Bacterium. Bulletin of the European Association of Fish Pathologists, 14, 19-23.

Türe, M. \& Boran, H. (2015). Phenotypic and genotypic antimicrobial resistance of Lactococcus sp. strains isolated from rainbow trout (Oncorhynchus mykiss). Bull. Vet. Inst. Pulawy, 59, 37-42.

Türe, M., Işıdan, H., Savaş, H. \& Kutlu, İ. (2012). PFGE metodu kullanılarak Lactococcus garvieae'nin genetik çeşitliliğinin ve yayılımının belirlenmesi. Su Ürünleri Merkez Araştırma Enstitüsü-Trabzon (TAGEM/HS/10/09/02/179) proje sonuç raporu, $61 \mathrm{~s}$.

Vela, A.I., Vazquez, J., Gibello, A., Blanco, M.M., Moreno, M., Liebana, P., Albendea, C., Alcala, B., Mendez, A., Dominguez, L. \& FernandezGarayzabal, J.F. (2000). Phenotypic and genetic characterization of Lactococcus garvieae isolated in Spain from Lactocococcosis outbreaks and comparison with isolates of other countries and sources. J. Clin. Microbiol., 38(10), 3791-3795. DOI: 10.1128/JCM.38.10.3791-3795.2000

Wang, C.Y., Shie, H.S., Chen, S.C., Huang, J.P., Hsieh, I.C., Wen, M.S., Lin, F.C. \& Wu, D. (2007). Lactococcus garvieae infections in humans: Possible association with aquaculture outbreaks. Int. J. Clin. Pract., 61, 68-73. DOI: 10.1111/j.1742-1241.2006.00855.x

Yiu, K., Siu, C., To, K., Jim, M., Lee, K., Lau, C. \& Tse, H. (2007). A rare cause of infective endocarditis; Lactococcus garvieae. Int. J. Cardiol., 114, 286287. DOI: $10.1016 /$ j.ijcard.2005.11.092

Zlotkin, A., Eldar, A., Ghittino, C. \& Bercovier, H., (1998). Identification of Lactococcus garvieae by PCR. J. Clin. Microbiol., 36, 983-985. DOI: 10.1128/JCM.36.4.983-985.1998 